\title{
ASPEK HUKUM USAHA WARALABA DI INDONESIA
}

\author{
Oleh : Mudassir Mathar
}

\begin{abstract}
ABSTRAK
Hakikatnya kegiatan usaha bisnis dapat dilaksanakan dengan berbagai macam bentuk dan cara sepanjang kegiatan usaha tersebut tidak bertentangan dengan ketentuan perundangundangan. Secara khusus bisnis waralaba di Indonesia telah diatur dengan perundang-undangan yang khusus mengatur bisnis waralaba baik dari segi perjanjiannya maupun etika bisnis yang lazim di dalam bisnis ini.

Peraturan yang digunakan adalah peraturan-peraturan yang mengatur tentang perjanjian yang terdapat dalam kitab Undang-Undang Hukum perdata (disingkat K.U.H.Perdata) dan peraturan lain yang mengaturnya ada didalam undang ketenagakerjaan. Undang-Undang pajak pertambahan nilai dan Undang-Undang pajak penghasilan serta Undang-Undang tentang wajib daftar perusahaan.
\end{abstract}

Selain itu perjanjian (Perikatan) waralaba dapat dikatakan suatu perjanjian yang tidak bertentangan dengan Undang-Undang, agama, ketertiban umum dan kesusilaan, karena itu perjanjian waralaba itu sah, dan oleh karena itu perjanjian itu menjadi Undang-Undang bagi mereka yang membuatnya, dan mengikat kedua belah pihak.

Rumusan yang mengatakan perjanjian franchising adalah suatu perjanjian dimana franchisee menjual produk atau jasa sesuai dengan cara dan prosedur yang telah ditetapkan oleh franchisor yang membantu melalui iklan, promosi, dan jasa-jasa nasihat lainnya. Pada tulisan ini kata franshisee diartikan waralaba, dengan demikian rumusan franchising tersebut diatas dapat diartikan rumusan waralaba.

Tulisan ini dilatarbelakangi oleh maraknya kegiatan usaha waralaba belakangan ini yang menjadi kecendrungan para pengusaha untuk memilih alternative usaha yang am an dari resiko kegagalan usaha dikarenakan kebingungan untuk memulai suatu usaha dan menghadapi persaingan usaha itu sendiri. Lebih jauh tulisan ini ingin mengetatahui peraturan-peraturan apa saja yang mengatur tentang perjanjian waralaba selain yang terdapat dalam kitab UndangUndang Hukum perdata (disingkat K.U.H.Perdata).

Kata-kata kunci : Perjanjian, Bisnis, pengusaha, prosedur, perusahaan. 


\section{A. Pendahuluan}

Walaupun Franchise dipopulerkan di negara Amerika Serikat, namun asal mula kata Franchise berawal dari Eropa, yaitu Perancis dan lnggris. Kata Franchise sendiri bermakna "kebebasan" (Freedom) ${ }^{1}$. Di masa itu, bangsawan diberikan wewenang oleh raja untuk menjadi tuan tanah pada daerah-daerah tertentu. Pada daerah tersebut, sang bangsawan dapat memanfaatkan tanah yang dikuasainya dengan imbalan pajak/upeti yang dikembalikan kepada kerajaan. Sistem tersebut menyerupai royalti, seperti layaknya bentuk Franchise saat ini.

Rumusan yang lain mengatakan perjanjian franchising adalah suatu perjanjian dimana franchiseemenjual produk atau jasa sesuai dengan cara dan prosedur yang telah ditetapkan oleh franchisor yang membantu melalui iklan, promosi, dan jasa-jasa nasihat lainnya. ${ }^{2}$ Pada tulisan ini kata franshisee diartikan waralaba, dengan demikian rumusan franchising tersebut diatas dapat diartikan rumusan waralaba.

Di Amerika Serikat sendiri, Franchise mengalami booming pada tahun 60- 70 an setelah berakhirnya Perang Dunia ke-2. Pada saat itu, banyak terjadi praktek penipuan bisnis yang mengaku sebagai Franchise, salah satunya dengan cara menjual sistem bisnis Franchise yang ternyata belum teruji keberhasilannya di lapangan. Selain itu, Franchisor pun lebih fokus untuk menjual Franchise milik mereka dibandingkan membangung dan menyempurnakan sistem bisnis Franchisenya. Banyak investor baru yang gagal oleh modus seperti ini, hal ini menjadi salah satu pendorong terbentuknya IFA (International Franchise Association) pada tahun 1960.

Salah satu tujuan didirikannya IFA adalah untuk menciptakan iklim industri bisnis Franchise yang dapat dipercaya, oleh karenanya IFA menciptakan kode etik Franchise sebagai pedoman bagi anggota-anggotanya. Walau begitu, kode etik Franchise masih perlu didukung oleh perangkat hukum agar dapat memastikan tiap-tiap pihak dalam industri ini terlindungi. Pada tahun 1978, Federal Trade Commission (FTC) mengeluarkan peraturan yang mewajibkan setiap

\footnotetext{
${ }^{1}$ Rooseno Harjowidigdo: Perspektif Pengaturan Perjanjian Franchise. Makalah PadPertemuan Ilmiah Tentang Frachise Jakarta 1993

${ }^{2}$ Hadiyanto, S.H, LL.M.: Aspek- Aspek Hukum Perpajakan Dalam Usaha Franchise, Makalah Pada Pertemuan Ilmiah Tentang Franchise, Jakarta, 1993
} 
Franchisor yang akan memberikan penawaran peluang waralaba kepada publik untuk memiliki UFOC (Uniform Franchise Offering Circular). UFOC adalah dokumen yang berisi informasi lengkap mengenai peluang bisnis Franchise yang ditawarkan, seperti: sejarah bisnis, pengelola, hal yang berkaitan dengan hukum, prakiraan investasi, deskripsi konsep bisnis, dan salinan dari perjanjian Franchise. Selain itu daftar nama, alamat dan nomor telepon dari pemilik Franchise adalah informasi yang diwajibkan. UFOC bertujuan untuk menyampaikan informasi yang cukup mengenai perusahaan untuk membantu calon Franchisee dalam mengambil keputusan.

1. Franchise (Waralaba) Di Indonesia

Pertumbuhan Franchise di Indonesia berawal dari masuknya waralaba asing pada tahun 80-90an. KFC, Mc Donalds, Burger King, Wendys adalah sebagian dari jejaring waralabaasing yang masuk ke Indonesia pada awal-awal berkembangnya Franchise di Indonesia. Perusahaanperusahaan waralaba lokal pun mulai bertumbuhan pada masa itu, salah satunya adalah yang termasuk pelopor waralaba lokal yaitu Es Teler 77.

Pada tahun 1991 berdiri Asosiasi Franchise Indonesia (AFI) sebagai wadah yang menaungi pewaralaba dan terwaralaba. Diharapkan dengan berdirinya AFI ini dapat tercipta industri waralaba yang kuat dan dapat menjadi pendorong utama dalam pertumbuhan ekonomi nasional yang berbasiskan usaha kecil dan menengah. Usaha Franchise (waralaba) merupakan jenis usaha yang dikecualikan tunduk pada UU No.5/1999 tentang Larangan Praktik Monopoli dan Persaingan Usaha Tidak Sehat. Ada dua hal penting untuk ini yaitu (i) apakah franchisee (terwaralaba) dilarang mengalihkan know how (yang diterimanya) kepada pihak lain dan (ii) guna mencegah terwaralaba bertindak curang memanfaatkan know how yang diperoleh dari franchisor (pewaralaba), haruskah perjanjian waralaba mengatur bahwa setelah perjanjian berakhir, terwaralaba dilarang melakukan usaha yang sama.

Pelaksanaan teknis waralaba di Indonesia diatur oleh Peraturan Pemerintah (PP) No.16/1997 tentang Waralaba (PP No.16/1997) dan Keputusan Menteri Perindustrian dan Perdagangan No. 259/MPP/Kep/7/1997 tentang Ketentuan dan Tata Cara Pelaksanaan Pendaftaran Usaha Waralaba.

PP No.1611997 juncto SK Menperindag mendefinisikan waralaba (franchise) adalah perikatan di mana salah satu pihak diberikan hak untuk memanfaatkan dan atau menggunakan 
hak atas kekayaan intelektual (HKI) ${ }^{3}$ atau penemuan atau ciri khas usaha yang dimiliki pihak lain dengan suatu imbalan berdasarkan persyaratan yang ditetapkan pihak lain tersebut, dalam rangka penyediaan dan/ atau penjualan barang barang dan/atau jasa. HAKI meliputi antar lain merek, nama dagang, logo, desain, hak cipta, rahasia dagang, dan paten.

PP NO.16/1997 dan SK Menperindag mensyaratkan waralaba diselenggarakan dengan perjanjian tertulis yang di buat dalam bahasa Indonesia serta mendasarkan pada hukum Indonesia. Pada prinsipnya, isi perjanjian diserahkan sepenuhnya kepada kedua pihak disesuaikan dengan kebutuhan masing-masing pihak. Sebagaimana prinsip pacta sun servada, maka perjanjian adalah berlaku sebagai undang-undang bagi pembuatnya.

Namun pasal 7 SK Menperindag memuat ketentuan mandatail (yang harus ada) mengatur mengenai isi klausul minimal yang harus diatur dalam perjanjian waralaba. Di antaranya (i) jangka waktu, minimal 5 tahun (i) nama dan jenis HKI,.penemuan atau ciri khas usaha misalnya sistem manajemen, cara penjualan atau penataan atau cara distribusi yang merupakan karakteristik khusus yang menjadi obyek waralaba dan (iii) hak dan kewajiban para pihak serta bantuan dan fasiliitas yang diberikan kepada terwaralaba.

Berdasarkan SK Menperindag, maka seakan tak masalah jika diatur dalam perjanjian bahwa terwaralaba dilarang mengalihkan know how yang diterimanya kepada pihak lain. Anggapan itu kurang tepat, sebab pasal 3 SK Menperindag membolehkan perjanjian waralaba disertai pemberian hak untuk membuat perjanjian waralaba lanjutan.

Artinya, pendapat yang secara absolut menolak terwaralaba untuk mengalihkan know how (salah satu elemen dalam HKI) yang diterimanya kepada pihak lain, bertentangan dengan SK Menperindag. Sebab, SK Menperindag memberikan opsi (bukan larangan) para pihak, apakah terwaralaba dilarang atau diperkenankan membuat perjanjian waralaba lanjutan (perjanjian secara tertulis antara terwaralaba utama dengan franchisee lanjutan).

Untuk menghindari adanya 'broker' waralaba yang menciptakan inefisiensi, SK Menperindag mengatur, jika terwaralaba diberi hak menunjuk lebih lanjut franchisee lanjutan,

\footnotetext{
${ }^{3}$ Masalah implementasi undang-undang HKI di Indonesia pada kenyataannya masih sangat lemah dibandingkan dengan negara-negara maju lainnya. Karenanya, UU HKI ini perlu divitalkan.
} 
francisee utama wajib mempunyai dan melaksanakan sendiri minimal melakukan waralaba pada satu tempat usaha.

Untuk mencegah terwaralaba bertindak curang memanfaatkan know how yang diperoleh dari pewaralaba, haruskah diatur dalam perjanjian bahwa setelah berakhirnya perjanjian, terwaralaba dilarang melakukan usaha yang sama dalam jangka waktu tertentu?

Sebab, bisa saja HKI adalah HKI franchisor sebelumnya, hanya mereknya saja yang berbeda.

Pengaturan itu melanggar pasal 19 UU No.5/19996 bahwa pelaku usaha dilarang melakukan satu atau beberapa kegiatan, baik sendiri maupun bersama pelaku usaha lain, yang dapat mengakibaratkan terjadinya praktik monopoli atau persaingan usaha tidak sehat berupa a.1. menolak atau menghalangi pelaku usaha tertentu untuk melakukan usaha yang sama pada pasar bersangkutan.

Meski waralaba berdasarkan pasal 50 UU No.5/1999 dikecualikan namun perjanjian waralaba yang melarang terwaralaba melakukan usaha yang sama dalam jangka waktu tertentu setelah berakhirnya perjanjian, adalah cenderung kurang memahami UU No.5/1999 dan HKI.

Sebab, pengecualian pasal 50 UU No.S/1999 hanya berlaku sepanjang perjanjian waralaba masih berlaku setelah perjanjian itu berakhir. Selain itu juga, HKI melindungi pemiliknya dari penggunaan tidak sah pihak lain. Seakan perjanjian waralaba hanya terkait dengan persoalan merek. Padahal berdasarkan PP No. 16/1997 HKI meliputi juga a.l. rahasia dagang dan paten.

Memang pasal itu menyebutkan bukan melakukan perjanjian, tapi melakukan kegiatan. Namun justru, gradasi perjanjian, tingkatannya lebih tinggi (sebab dua arab dan mengikat pihak yang sepakat untuk melakukannya) dari sekadar kegiatan sepihak (pihak lawan tidak terikat untuk mematuhinya).

Karenanya, eks-franchisee dapat melakukan usaha di bidang yang sama pasca berakhirnya perjanjian waralaba. Bahkan, ketika masih terikat dalam perjanjian waralaba. Dengan syarat, tidak melanggar perjanjian waralaba yang disepakati (termasuk ketentuan yang fakultatif) dan tidak melanggar HAKI yang dimiliki franchisor atau eks-franchisor, 
Jika eks-franchisor merasa telah disalahgunakan know how yang pernah diberikannya kepada eks-franchisee, maka eks-franchaisor menggugat melalui Pengadilan Niaga atas penggunaan hak paten dan/atau rahasia dagang yang digunakan secara tidak sah oleh eksfranchisee.

\section{B. Pembahasan}

a. Perjanjian Waralaba

Dalam hokum perjanjian, perjanjian waralaba merupakan perjanjian khusus karenanya tidak banyak dijumpai dalam Kitab Undang-Undang Hukum Perdata. Perjanjian ini dapat diterima dalam hukum karena didalam Kitab Undang-Undang Hukum Perdata ditemui satu pasal yang mengatakan adanya kebebasan berkontrak. Pasal itu mengatakan bahwa perjanjian yang dibuat secara sah berlaku sebagai Undang-Undang bagi mereka yang membuatnya (Pasal 1338 Kitab Undang-Undang Hukum Perdata).

Perjanjian dibuat secara sah artinya bahwa perjanjian itu telah memenuhi syarat-syarat yang ditentukan dalam undang-undang. Artinya perjanjian itu tidak bertentangan dengan Agama dan ketertiban umum, dan tidak bertentangan dengan kesusilaan, dan Undang-Undang itu sendiri. Perjanjian waralaba dapat dikatakan suatu perjanjian yang tidak bertentangan dengan Undang-Undang agama ketertiban umum dan kesusilaan karena itu perjanjian waralaba itu sah, dan oleh karena itu perjanjian itu menjadi Undang-Undang bagi mereka yang membuatnya, dan mengikat kedua belah pihak.

Pada dasarnya waralaba berkenan dengan pemberian izin oleh seorang pemilik waralaba (franchisor) kepada orang lain atau beberapa orang untuk menggunakan sistem atau cara pengoperasian suatu bisnis. Pemberian izin ini meliputi untuk menggunakan hak-hak pemilik waralaba yang berada dibidang hak milik intelektual (lntelectual Property Rights).

Perjanjian lisensi biasa tidak sama dengan pemberian (perjanjian) lisensi waralaba. Kalau pada pemberian (perjanjian) lisensi biasanya hanya meliputi pemberian izin lisensi bagi penggunaan merek tertentu. Sedangkan pada waralaba, pemberian izin lisensi meliputi pelbagai macam hak milik intelektual. Keseluruhan hak-hak milik intelek bahwa alat-alat dibeli atau disewakan darinya. Selain yang disebut diatas perjanjian waralaba (franchising): Pemberian lisensi hukum tentang nama perniagaan, merek, model, desain dan sebagainya. Bidang-bidang 
hukum itu dapat dikelompokkan dalam bidang hukum perjanjian dan dalam bidang hukum tentang hak milik intelektual.

b. Perjanjian-Perjanjian yang Berkaitan dengan Waralaba

Perjanjian-perjanjian yang terdapat dalam waralaba tidak saja tentang perjanjian pemberian lisensi tetapi lebih dari itu. Masih ada Perjanjian-perjanjian lain yang terkait dengan waralaba tersebut, seperti :

1. Perjanjian Tentang Hutang Piutang.

Seorang calon pengguna waralaba memerlukan pinjaman guna pembayaran "fee"(biaya-biaya). Adakalanya pinjaman ini diperoleh dari pihak lain, tetapi ada kemungkinan waralaba memberikan pinjaman kepada pengguna waralaba untuk dipergunakan sebagai modal kerja.

\section{Penyewaan Tempat Usaha}

Tempat usaha ini memegang peranan penting bagi pemasaran. Kadangka pemilik waralaba memiliki bagian yang mengadakan penelitian tentang tempat usaha ini, mencari tempat usaha yang letaknya strategis lalu membeli atau menyewanya, dan kemudian menyewakannya kepada pengguna waralaba (franchisee).

\section{Perjanjian Pembangunan TempatUsaha}

Pada tempat usaha waralaba tertentu masyarakat yang ingin membangun agar bangunan-bangunannya dapat dibuat secara khas (Khusus) sesuai dengan persyaratan yang nantinya diberikan oleh pemilik waralaba (franchisor). Pengguna waralaba (franchisee) boleh memakai pemborongnya sendiri, tetapi dalam banyak perakteknya kadang kala pemilik waralaba (franchisor) mempunyai hak veto dalam mendesain dan menata tempat usahanya agar sesuai dengan bentuk yang telah lazim mereka pergunakan dalam bisnisnya.

\section{Penyewaan Peralatan}

Ada kemungkinan bahwa pihak pemilik waralaba (franchisor) mensyaratkan bahwa alat-alat dibeli atau disewakan darinya. Selain yang disebut diatas perjanjian waralaba (franchising) antara lain :

1. Melibatkan lisensi nama perniagaan, logo type, dan merek jasa.

2. Melibatkan nama baik perusahaan, dan pengguna waralaba memanfaatkan hal ini. 
3. Melibatkan pemberian informasi rahasia dan keterampilan atau kecakapan tehnik. Informasi rahasia ini memegang peranan penting dalam waralaba.

c. Pokok-Pokok Peraturan yang Terkait dengan bisnis Waralaba

Dari judul "Aspek Hukum Waralaba" maka yang dimaksudkan adalah peraturanperaturan yang terkait dengan bisnis waralaba itu sendiri. Banyak macam peraturan-peraturan yang terkait diantaranya adalah :

\section{Berhubungan Dengan Hukum Perjanjian}

Dalam hukum perjanjian harus memenuhi syarat-syarat yang ditentukan oleh peraturan yang berlaku yang dijumpai dalam Kitab Undang-Undang Hukum Perdata ( disingkat K.U.H.Perdata).

Agar perjanjian yang dibuat oleh para pihak menjadi sah harus dipenuhinya syarat-syarat yang ditentukan dalam pasal 1320 K.U.H.Perdata yaitu sebagai berikut:

1. Adanya kesepakatan dari para pihak yang membuat perjanjian. Artinya untuk membuat perjanjian tidak boleh ada paksaan, tidak boleh ada penipuan, dan tidak boleh ada kekhilafan. Kalau ada perjanjian dibuat dengan tidak sepakat maka perjanjian itu dapat dimintakan pembatalannya.

2. Para pihak harus cakap (wenang) bertindak dalam hukum. Artinya pihak-pihak yang membuat perjanjian tersebut harus cakap (wenang) untuk membuat perjanjian. Maksudnya orang yang cakap (wenang) adalah orang yang sudah dewasa, orang yang tidak berada dibawah pengampuan (curatele) seperti orang yang sakit otak, mata gelap,pemabok, penjudi, dan sebagainya.

3. Sesuatu hat tertentu. Artinya yang menjadi objek perjanjian tersebut, misalnya perjanjian waralaba jenis apa, makanankah, restorankah atau dan sebagainya. Kalau hal ini tidak dapat ditentukan maka perjanjian tersebut batal demi hukum, artinya perjanjian tak sah.

4. Sebab yang halal. Artinya perjanjian itu dibuat tidak bertentangan denganUndang-Undang, agama, ketertiban umum, dan kesusilaan. Kalau ini tak halal, artinya bertentangan dengan undang-undang, agama, ketertiban umum dan kesusilaan, maka perjanjian yang dibuat itu tidak sah. 
Keempat syarat inilah yang harus dipenuhi. Apabila sudah dipenuhi, barulah perjanjian itu disebut perjanjian yang sah. Apabila perjanjian dibuat secara sah maka berlakuklah ia sebagai Undang-Undang bagi pihak yang membuatnya (Pasal 1338 K.U.H.Perdata).

2. Berhubungan Dengan Hak Milik Intelektual

Yang dimaksud dengan hak milik intelektual (lntelectual Property Right) juga disebut hak milik immaterial adalah: hak milik yang tercipta berdasarkan atau hadir dari karya, kreasi, daya fikir atau inteletualita seseorang, dengan perkataan lain hak atas kekayaan yang timbul atau lahir dari intelektualita seseorang ${ }^{4}$. Hak milik intelekual secara umum dapat dikelompokkan dalam dua kelompok, yaitu:

1. Hak milik induktri (industrial property) yang terdiri dari:

a. Hak paten (patent)

b. Hak merek (merk)

c. Hak desain produk indutri (industrial design product)

2. Hak cipta (copyright)

Di depan telah disampaikan rumusan tentang waralaba (franching), dimana rumusan itu nyata bahwa waralaba merupakan konsep bisnis yang berkaitan dengan hak paten, hak merek, hak cipta, dan disain produk industri. Dengan adanya perjanjian waralaba mengakibatkan adanya pemberian hak untuk menggunakan sistem waralaba yang bersangkutan. Pemberian hak-hak tersebut ialah :

a. Hak merek

Hak merek adalah tanda yang berupa gambar, nama, kata, huruf -huruf, angka-angka, susunan warna, atau kombinasi dari unsur-unsur tersebut yang memiliki daya pembeda dan digunakan dalam kegiatan perdagangan barang dan jasa. (Pasal 1 Nomor 1 Undang-Undang No.19 Tahun 1992- Undang-Undang tentang Merek.) Suatu merek dianggap sah apabila merek itu telah didaftarkan dalam Daftar Merek. Barang siapa yang pertama yang mendaftarkan, dialah yang

\footnotetext{
${ }^{4}$ Lihat lebih jauh Baros, Wan Sadjaruddin. Beberapa Sendi Tentang Hukum Perikatan. Medan: USU Press Medan, 1985, hIm. 50.
} 
berhak atas merek, dan secara eksklusif (exclusive) dia dapat memakai merek tersebut, sedang pihak lain tidak boleh memakainya, kecuali dengan izin. Tanpa pendaftaran tidak ada hak atas merek, lnilah terdapat lebih ban yak kepastian. Hal ini tersimpul dalam pasal 3 Undang-Undang No.19 Tahun 1992 tentang Merek yang menyatakan: "Hak atas merek adalah hak khusus yang diberikan Negara kepada pemilik merek yang terdaftar dalam daftar merek umum untuk jangka waktu tertentu menggunakan sendiri merek itu atau memberi izin kepada seorang atau beberapa orang secara bersama -sama atau badan hukum untuk menggunakannya" .

Jelas bahwa penekanan terletak pada pendaftaran yang menimbulkan hak atas merek dan bukan pada pemakaian pertama. Perlu pula diperhatikan Pasal 4 Undang-Undang No. 19 Tahun 1992: "(1) Merek hanya didaftar atas dasar permintaan yang diajukan pemilik merek yang beritikad baik". Perlu dijelaskan bahwa pemakaian merek berbeda dengan kepemilikan merek. Kepemilikan merek dapat diperoleh dengan cara pewarisan, wasiat, hibah, perjanjian atau sebabsebab lain yang dibenarkan oleh Undang-undang . (Menurut pasal 41 ayat 1 Undang-Undang No.19 Tahun 1992).

Sedangkan pemakaian merek dapat dilakukan oleh pemilik sendiri, maupun oleh orang lain dengan izin pemilik merek. lzin ini dapat melalui lisensi atau franchise (waralaba). Apabila diasumsikan bahwa esensial franchise (waralaba itu adalah perjanjian pemberian lesensi, sesuailah dengan azas kebebasan berkontrak yang diatur dalam pasal 1338 Kitab Undang-Undan Hukum Perdata dan pasal 1320 Kitab Undang-Undang Hukum Perdata. Oleh karena itu ketentuan-ketentuan lesensi yang terdapat dalam Undang-Undang tentang merek dapat diterapkan pada perjanj ian waralaba franchising). Pemberian lisensi kepada orang lain dilakukan dengan perjanjian untuk menggunakan mereknya baik untuk sebagian ataupun seluruhnya jenis barang atau jasa yang termasuk dalam satu kelas. Artinya tidak setiap orang boleh memakai merek orang lain tanpa izin pemilik merek yang bersangkutan. Apabila seseorang memakai merek orang lain tanpa izin pemilik merek maka pemilik merek dapat menuntut pemakai merek tanpa izin itu. Termasuk merek dalam waralaba. Tuntutan itu dapat dilakukan berdasarkan hukum perdata maupun hukum pidana. Hal ini dapat disimpulkan dari pasal 72 sampai dengan pasal 76 dan pasal 81 sampai pasal Undang-Undang Merek (Undang-Undang No.19 Tahun 1992). Inti yang penting dari pasal-pasal tersebut diatas yang perlu diketahui adalah:

a. Pasal 72 ayat (1) : 
Pemilik terdaftar dapat mengajukan gugatan terhadap orang atau badan hukum yang menggunakan mereknya. yang mempunyai persamaan baik pada pokoknya atau pada keseluruhannya secara tanpa hak, berupa permintaan ganti rugi dan penghentian pemakaian merek tersebut.

\section{b. Pasal 76 :}

Hak mengajukan gugatan sebagaimana diatur dalam bab ini (maksudnya Bab VIII tentang gugatan ganti rugi, yang diawali pasal 72) tidak mengurangi hak Negara untuk melakukan tindak pidana dibidang merek.

Adapun ketentuan pidana yang dapat dituntutkan pada pemakai merek orang lain tanpa hak (izin pemilik) adalah :

Pasal 81 :

Setiap orang yang dengan sengaja dan tanpa hak menggunakan merek yang sama pada keseluruhannya dengan merek terdaftar milik orang lain atau badan hukum lain untuk barang atau jasa sejenis yang diproduksi dan akan dperdagangkan, dipidana penjara paling lama tujuh tahun dan denda paling banyak Rp.1 00.000.000,-( seratus juta rupiah).

\section{Pasal 82 :}

Setiap orang yang dengan sengaja dan tanpa hak menggunakan merek yang sama pada keseluruhannya dengan merek terdaftar milik orang lain atau badan hukum lain untuk barang atau jasa sejenis yang diproduksi dan atau diperdagangkan, dipidana penjara paling lama lima tahun dan denda paling banyak Rp.50.000.000,- (lima puluhjuta rupiah).

Pasal 83: Tindak pidana sebagaimana dimaksud dalam pasal 81 dan 82 adalah kejahatan.

Pasal 84 : Setiap orang yang memperdagangkan barang atau jasa tersebut menggunakan ayat (1) merek terdaftar milik orang lain secara tanpa hak dipidana dengan pidana kurungan paling lama satu tahun atau dan denda paling banyak Rp.10.000.000,-(sepuluh juta rupiah). Ayat (2): Tindakan pidana sebagaimana dimaksud dalam ayat (1) adalah pelanggaran.

Dari ketentuan diatas dapatlah disimpulkan bahwa setiap orang yang menggunakan merek dalam waralaba tanpa hak dapat dituntut baik tuntutan ganti rugi maupun dipidana penjara dan ditambah denda. 


\section{b. Hak Paten (Undang-Undang No.6 Tahun 1986)}

Paten adalah hak khusus yang dibenkan Negara kepada penemu atas hasil penemuannya dibidang tehnologi, untuk selama waktu tertentu melaksanakan sendiri penemuannya tersebut atau memberikan persetujuannya kepada orang lain untuk melaksanakannya (Pasal 1 ayat 1). Penemuan adalah kegiatan pemecahan masalah tertentu dibidang tehnologi yang dapat berupa proses atau hasil produksi atau penyempurnaan dan pengembangan proses atau hasil produksi (Pasal 1 angka 2 Undang-Undang Paten).

Dari Pasal 1 angka 2 UUP dapat disimpulkan bahwa penemuan adalah kegiatan pemecahan masalah tertentu dibidang teknologi yang dapat berupa:
a. Proses produksi, atau
b. Hasil produksi, atau
c. Penyempurnaan proses produksi, atau
d. Penyempurnaan hasil produksi, atau
e. Pengembangan proses produksi, atau
f. Pengembangan hasil produksi.

Suatu paten bila dialihkan kepada pihak penerima maka pengalihan itu harus dilakukan secara tertulis. Jika dilakukan dengan perjanjian harus dengan akta notaris. Dan wajib didaftarkan pada Kantor Paten dan dicatat dalam Daftar Umum. Apabila dilakukan tidak sesuai dengan ketentuan maka pengalihan itu tidak sah dan tidak berlaku (Pasal 73 Undang-Undang Paten).

Ketentuan ini menyatakan bahwa apabila ada orang lain memakai, melaksanakan paten milik orang lain yaitu pemakaian hak untuk menikmati manfaat ekonomi dari paten, maka perbuatannya itu tidak sah dan diet karena itu dapat dituntut. Pengalihan pemilihan paten baik seluruhnya atau sebagian dapat terjadi karena pewarisan, hibah, wasiat, perjanjian, dan sebab-sebab lain yang dibenarkan undang-undang. Pelanggaran terhadap paten dapat dituntut secara perdata dan pidana. Setiap orang yang menggunakan paten tanpa izin pemegang hak paten, dapat dituntut oleh pemegang (pemilik) hak paten berupa ganti rugi dan penyerahan kepadanya seluruh atau sebagian dari paten itu (Pasal 121 dan Pasal 122 Undang-Undang Paten). 
Disamping itu dapat juga dituntut secara pidana bagi setiap orang dengan sengaja dan tanpa hak melanggar hak pemegang paten dengan melakukan salah satu tindakkan sebagai membuat, menjual, menyewakan, menyerahkan, memakai, menyediakan untuk dijual atau disewakan atau diserahkan hasil produksi yang diberikan paten, menggunakan proses produksi yang diberikan paten untuk membuat barang dan tindakan lainnya, dipidana dengan pidana penjara paling lama tujuh tahun dan denda paling banyak Rp. 100.000.000,- (seratus juta rupiah). Pada paten sederhana dikenakan hukuman penjara lima tahun dan denda Rp.50.000.000,- (lima puluhjuta rupiah). Tindak pidana ini merupakan perbuatan kejahatan. (Hal ini tersimpul dalam pasal 126 s/d pasal 129 Undang-Undang Paten).

\section{c. Hak Cipta}

Pengaturan hak cipta dijumpai dalam Undang-Undang No.19 Tahun 2002. Pasal 2 Ayat 1 : Hak Cipta merupakan hak eksklusif bagi Pencipta atau Pemegang Hak Cipta untuk mengumumkan atau memperbanyak Ciptaannya, yang timbul secara otomatis setelah suatu ciptaan dilahirkan tanpa mengurangi pembatasan menurut peraturan perundang-undangan yang berlaku.

Ayat 2 : Pencipta atau Pemegang Hak Cipta atas karya sinematografi dan Program Komputer memiliki hak untuk memberikan izin atau melarang orang lain yang tanpa persetujuannya menyewakan Ciptaan tersebut untuk kepentingan yang bersifat komersial.

Ciptaan adalah basil setiap karya pencipta dalam bentuk khas apapun juga dalam lapangan ilmu, seni dan sastra. (pasal 2 ayat 1 Undang-Undang Hak cipta). Hak dari ciptaan dapat beralih pada orang lain melalui lima cara, yaitu:

1. Warisan

2. Hibah

3. Wasiat

4. Dijadikan milik negara

5. Perjanjian yang harus dilakukan dengan akta mengenai wewenang yang disebut dalam akta (Pasal 3 ayat 2 Undang-Undang Hak Cipta). 
Setiap orang yang mempergunakan ciptaan orang lain tanpa izin pencipta dapat dituduh sebagai perbuatan kejahatan dan ditindak dengan ketentuan pidana, seperti tersebut dalam pasal 72 di bawah ini.

ayat (2) : Barangsiapa dengan sengaja dan tanpa hak melakukan perbuatan sebagaimana dimaksud dalam Pasal 2 ayat (1) atau Pasal 49 ayat (1) dan ayat (2) dipidana dengan pidana penjara masing-masing paling singkat 1 (satu) bulan dan atau denda paling sedikit Rp1.000.000,00 (satu juta rupiah), atau pidana penjara paling lama tujuh tahun dan/atau denda paling banyak Rp 5.000.000 000.00 (lima miliar rupiah).

ayat (2): Barangsiapa dengan sengaja menyiarkan, memamerkan, mengedarkan, atau menjual kepada umum suatu Ciptaan atau barang hasil pelanggaran Hak Cipta atau Hak Terkait sebagaimana dimaksud pada ayat (1) dipidana dengan pidana penjara paling lama 5 (lima) tahun dan/atau denda paling banyak $\mathrm{Rp}$ 500.000.000,00 (lima ratus juta rupiah).

Selain menyangkut Hak Milik Intelektual, terhadap perjanjian waralaba masih terdapat lagi ketentuan-ketentuan/peraturan peraturan yang berhubungan dengan waralaba tersebut, seperti yang tersebut di bawah ini.

1. Berhubungan dengan hukum ketenagakerjaan

Hukum ketenagakerjaan pada hakekatnya mempunyai peranan untuk menjamin kedudukan sosial ekonomi tenaga kerja serta arah yang harus ditempuh dalam mengatur hubungan sosial ekonomi tenaga kerja. Selain itu hukum ketenagakerjaan mempunyai fungsi untuk melindungi hak-hak fundamental pekerja dan pengusaha serta menetapkan standard minimal, mengatur keseimbangan antara hak dan kewajiban serta menciptakan ketenangan kerja dan ketentraman usaha. Hukum ketenagakerjaan berlaku pada perjanjian waralaba, apabila hubungan antara pemegang hak waralaba dan pekerja dalam usaha waralaba sebagai hubungan pekerja. Artinya pengusaha waralaba memperkerjakan orang lain sebagai pekerja, terciptalah hubungan kerja. Dan antara keduanya punya hak dan kewajiban.

Hak pekerja antara lain:

- Hak atas upah

- Hak atas keselamatan kerja dan kesehatan kerja 
Hal ini diatur dalam Undang-Undang No.13 tahun 2003. Dan pengusaha seain mempunyai kewajiban pada pekerja untuk membayar upah dan sebagainya, pengusaha waralaba juga punya kewajiban kepada pemerintah, setidaknya melaporkan kegiatan usahanya setiap tahun. Hal ini ditentukan dalam Undang-Undang No.7 Tahun 1981.

2. Berhubungan dengan peraturan Perpajakan

Dalam rangka bisnis waralaba terdapat transaksi yang terutang, yaitu:

a. Penyerahan jasa dari pemilik waralaba kepada pemakai berupa hak-hak penggunaan merek (merek dagang) untuk dipergunakan oleh pemakai waralaba.

b. Penyerahan barang kena pajak (BKP) oleh pemakai waralaba dan atau pemilik waralaba dalam negeri kepada pihak lain. Hal ini ditentukan dalam Undang-Undang PPN Tahun 2000.

c. Selain dari pada itu bahwa pemakai waralaba yang memperoleh penghasilan juga dikenakan Pajak Penghasilan (PPh), hal ini ditentukan pasal 17 UU-PPh Tahun 2000, yaitu :

- $5 \%$ untuk penghasilan sampai dengan Rp.25.000.000,- (dua puluh lima juta rupiah).

$-10 \%$ untuk penghasilan diatas Rp. 25.000.000,. (dua puluh juta rupiah) sampai dengan Rp.50.000.000,- (lima puluh juta rupiah).

-15\% untuk penghasilan diatas Rp. 50.000.000,- (lima puluh juta rupiah) sampai dengan Rp.100.000.000,- (seratus juta rupiah).

- $25 \%$ untuk penghasilan diatas Rp.100.000.000,- (seratus juta rupiah). sampai dengan Rp.200.000.000,-(dua ratus juta rupiah).

- 35 \% untuk penghasilan diatas Rp.200.000.000,- (dua ratus juta rupiah). sampai dengan tak terhingga

Dalam menghitung besarnya $\mathrm{PPh}^{5}$ terhutang tersebut, dapat dikurangkan, biaya-biaya yang dikeluarkan dalam rangka untuk memperoleh, menagih dan mempertahankan penghasilan (3 M) yang meliputi antara lain pembayaran royalti kepada pemilik waralaba.

- PPh atas pembayaran Royalti. Sesuai dengan ketentuan pasal 23 UU-PPh Tahun 2000, pemakai waralaba sebagai wajib pajak dalam Negeri wajib memotong PPh sebesar $15 \%$ dari jumlah bruto

\footnotetext{
${ }^{5}$ lihat pasal 17 UU No. 17 Tahun 2000 tentang Pajak Penghasilan
} 
dan atas pembayaran Royalti kepada pemilik waralaba yang merupakan wajib pajak dalam negeri.

Pasal 26 UU-PPh Tahun 2000 : Apabila pembayaran Royalti dilakukan oleh pemakai waralaba kepada pemilik waralaba di luar negeri, maka pemakai waralaba sebagai wajib pajak dalam negeri wajib memotong $\mathrm{PPh}$ pasal 26, sebesar $20 \%$ dari pembayaran bruto royalti. pemotongan $\mathrm{PPh}$ Pasal 26 ini bersifat final, artinya pemilik waralaba sebagai wajib pajak luar negeri tidak perlu mengisi dan menyampaikan SPT-PPh.

3. Berhubungan dengan wajib daftar perusahaan

Daftar perusahaan adalah daftar catatan resmi yang diadakan menurut atau berdasarkan ketentuan Unang-Undang ini dan atau peraturan-peraturan pelaksanaannya, dan memuat hal-hal yang wajib didaftarkan oleh setiap perusahaan serta disahkan oleh pejabat yang berwenang dari kantor pendaftaran perusahaan. (Pasal 1 huruf a Undang-Undang R.I Nomor 3 Tahun 1982, tentang daftar perusahaan). Dalam ketentuan-ketentuan Undang-Undang tersebut ditentukan bahwa tujuan dari Daftar Perusahaan adalah menjamin kepastian berusaha.

Setiap perusahaan wajib didaftarkan dalam Daftar Perusahaan, terkecuali : Perusahaan Negara yang berbentuk perusahaan jawatan (PERJAN) seperti yang diatur dalam UndangUndang No.9 Tahun 1969, dan Perusahaan Kecil Perorangan yang dijalankan oleh orang pribadi pengusahanya sendiri atau dengan memperkerjakan hanya anggota keluarganya sendiri yang terdekat serta tak memerlukan izin usaha dan tidak merupakan suatu badan hukum atau suatu persekutuan.

Perusahaan yang wajib didaftar dalam Daftar Perusahaan adalah setiap perusahaan yang berkedudukan menjalankan usahanya di wilayah Negara Rapublik Indonesia, termasuk Kantor Cabang, kantor pembantu, anak perusahaan serta agen dan perwakilan dari perusahaan itu yang mempunyai wewenang untuk mengadakan perjanjian, perusahaan itu ada yang berbentuk Badan Hukum, termasuk Koperasi, Persekutuan, Perorangan, dan perusahan lainnya (pasal 7 dan 8 Undang-Undang No.3 Tahun 1982).

Berdasarkan ketentuan tersebut diatas, suatu usaha bisnis waralaba termasuklah di dalamnya, walaupun mungkin diusahakan oleh perorangan yang bukan Badan Hukum. Pemilik atau pengusaha waralaba yang wajib melaksanakan pendaftaran ini, atau boleh juga dikuasakan 
pad a orang lain untuk mendaftar. Dalam ketentuan Undang-Undang ini pada pasal 32 ditentukan bahwa, barangsiapa dengan sengaja atau karena kelalaiannya tidak melaksanakan kewajibannya mendaftarkan perusahaannya diancam dengan pidana selama-lamanya 3 (tiga) bulan atau denda setinggi-tingginya Rp.3.000.000,-(tiga juta rupiah).

Pasal 33 : Menentukan bahwa apabila melakukan atau menyuruh melakukan pendaftaran secara keliru atau tidak lengkap dalam daftar Perusahaan diancam dengan pidana kurungan selama lamanya 3 (tiga) bulan atau denda setinggi-tingginya Rp.1.500.000,- (satu juta lima ratus ribu rupiah). Hal ini merupakan pelanggaran.

Disamping pendaftaran dalam Daftar Perusahaan, maka usaha waralaba juga diwajbkan mempunyai Surat Izin Usaha Perdagangan (S.I.U.P), sesuai dengan ketentuan Keputusan Menteri Perdagangan No.:1456/Kp/XII/84. Surat Izin Usaha Perdagangan (S.I.U.P.) adalah izin untuk dapat melaksanakan kegiatan perdagangan.

Yang dimaksud dengan perdagangan adalah kegiatan jual beli barang atau jasa yang dilakukan secara terus menerus dengan tujuan pengalihan hak atas barang atau jasa dengan disertai imbalan atau kompensasi.

Setiap perusahaan yang melakukan kegiatan perdagangan di wajibkan memiliki S.I.U.P. (Pasal3 Kep.Men.Dag.No.: 1458/Kp/XIJ/84). Waralaba (franchhise) sebagai salah satu kegiatan usaha perdagangan \wajib mempunyai Surat lzin Usaha Perdagangan (S.I.U.P.)

\section{c. Penutup}

Pada dasarnya bahwa peraturan-peraturan yang berlaku pada perjanjian waralaba (franchising), sesudah adanya peraturan yang khusus untuk mengatur waralaba, yaitu:

a. Peraturan hukum tentang perjanjian khususnya yang dijumpai pada pasal 1320 Kitab UndangUndang Hukum Perdata yaitu syarat-syarat sahnya suatu perjanjian. Kemudian pasal1338 Kitab

Undang-Undang Hukum Perdata tentang ketentuan yang dapat membenarkan tentang perjanjian waralaba.

b. Peraturan tentang Hak Milik Intelektual, yaitu hak paten, hak merek dan hak cipta sesuai Undang-Undang No.19 Tahun 2002.

c. Peraturan hukum tentang Perpajakan yaitu Pajak Pertambahan Nilai (PPN) Tahun 2000 dan Pajak penghasilan (PPh) Tahun 2000. 
d. Peraturan hukum tentang Ketenagakerjaan sesuai Undang- Undang No.13 ahun 2003.

e. Peraturan hukum tentang Daftar Perusahaan sesuai dengan Undang-Undang Nomor 3 Tahun 1982. dan peraturan tentang Surat Izin Usaha Perdagangan (S.I.U.P.O, sesuai dengan Keputusan Menteri Perdagangan Nomor: 1458/Kp/XII/84.

Tidak menutup kemungkinan dikemudian hari dengan pesatnya perkembangan pasar waralaba dan kegairahan pengusaha dapat diciptakan lagi jenis usaha waralaba dengan konsep Syariah yang lebih memberikan kenyamanan, keamanan dan keuntungan bagi kedua belah pihak secara adil sesuai dengan syariat islami yang mengandung makna antara lain :

a. Berusaha hanya untuk mengambil yang halal dan baik

b. Halal cara perolehan : melalui perniagaan yang berlaku secara ridho sama ridho.

c. Halal cara perolehan : berlaku adil dan menghindari keraguan

d. Halal cara penggunaan : saling tolong menolong dan menghindari resiko yang berlebihan.

Demikian antara lain pokok-pokok yang dapat diambil sebagai kesimpulan dari sajian Aspek Hukum Waralaba, dengan harapan ada manfaatnya bagi pembaca. Wallahu a 'lam bishshowa. 